\author{
Roman Nevzorov \\ Department of Aviation Tactics \\ Ivan Kozhedub Kharkiv National Air Force University, Kharkiv, Ukraine \\ E-mail: roman.nevzorov1970@gmail.com \\ ORCID: https://orcid.org/0000-0003-1496-2465 \\ Researcher: https://publons.com/researcher/1326985/roman-nevzorov
}

\title{
Quality management of ground training of future pilots in the conditions of modern educational space in Ukraine
}

\begin{abstract}
In this research, based on the analysis of scientific sources and empirical material, the features and requirements for the quality of ground training of future tactical aviation pilots in an institution of higher military education are characterized. It is noted that the signs in the XXI century are digitalization, informatization and humanization of education, and the leading pedagogical tool is modern information technologies of teaching. The purpose of the article is to improve the quality management system of ground training of future tactical aviation pilots in an institution of Higher Military Education (SVVO) in the conditions of a modern educational space based on a competent model of training military specialists by means of digital and innovative pedagogical technologies; introduction into the practice of a higher military educational institution of tools for managing the quality of training military specialists. Methodology of the article: analysis of domestic and foreign philosophical, psychological, pedagogical and methodological literature; abstraction and concretization to define the concept of mechanisms of higher military education in a modern educational space, systematization, generalization. Results. The management of the ground training system for combat flights of future tactical aviation pilots is updated by the lack of its disclosure by theorists of military pedagogical science. Practical implictions: influence on the quality of development of the military organization of the state. Value/origiality. Today in Ukraine there is no integral well-founded pedagogical system of ground training for combat flights of future military pilots as a result of insufficient scientific study of this problem in pedagogical theory as a whole.
\end{abstract}

\author{
Keywords \\ Management, \\ educational space, \\ competence, quality, \\ training, ground \\ training, future pilot
}

JEL: I21, C90, Y40

\section{Introduction}

Military education is a part of National Education and one of the factors determining the quality of development of the military organization of the state. The problems of assessing the quality of training of future tactical aviation pilots in an institution of higher military education in Ukraine remain relevant. Such scientists as: S. Asriyan, O. Vorona, Yu. Vorontsov, D. Gander, E. Derevyanko, N. Zavalova, V. Kozlov, P. Korchemny are considered in relation to psychological and pedagogical readiness and professional competence. N. Ladogubets, V. Lapa, B. Lomov, O. Makarevich, R. Makarov, V. Marishchuk, O. Marchenko, K. Platonov, T. Plachinda, E. Surkova, V. Yagupov and others.

A qualitatively new, fundamental feature of today's world of the XXI century is its dynamism, variability of forms and processes. As a result, the current challenges addressed to him in the field of education in general and higher (professional) in particular are also characterized by a variety of manifestations and high rates of change. In fact, the effectiveness of educational systems and approaches directly depends on the adequacy and speed of response to these challenges, the ability to conceptual and methodological flexibility. The dynamic pace of key processes of globalization and integration in education objectively requires a fundamental scientific understanding of both the new essence of education and the educational space in general, and their new components and subsystems in particular. Naturally, the pedagogical subsystem of ground training of future tactical aviation pilots in the SVVO also requires the development of a modern theoretical base and the establishment of an institutional status in these conditions.

The modern dynamic globalized world has forced the international scientific community to take a fresh look and interpret the entire field of Education. Changes in approaches, paradigms, and conceptual vision have led to the emergence and widespread adoption of the concept of "Education Area" at the international level.

In general, the latest scientific trend determines the essence of modern key processes in various public spheres and on a global scale in the format of the formation and development of a certain space associated with the universal trend of integration of the modern world (Kasiarum N., 2013). As N. V. Kasyarum rightly notes, "the term "educational space" reflects certain changes in the views of scientists on the problem of society's influence on the conditions of personal development, interaction between society and the individual" (Kasiarum N., 2013). This concept, within the framework of common basic standards, ensures the interdependence and interaction of its components, as well as as a complex hierarchical structure, a pyramid of spaces of different levels - global, continental, 
a separate country and region, local (separate educational institution), family, personal (Hershunskyi B. S., 1997). It is also advisable to consider it as a sphere of social activity, where purposeful socio-cultural reproduction of a person, formation and development of personality is carried out (Kasiarum N., 2013).

\section{Digitalization of modern society and education}

The educational space of society is a form of social unity of people, which is created as a result of their joint educational activities, the purpose of which is determined by the needs of educational subjects. We fully agree with the conclusion of N. V. Kasiarum regarding the purpose of the op in creating the necessary conditions for the transfer of social experience in society, which is provided through special infrastructure, information support and social conditions (Kasiarum N., 2013).

In the world pedagogical discourse, various types of educational space are considered: information and educational (associated with the global spread of modern information technologies and their application in education), professional and educational (dialectic of communication between education and professional self-expression of the individual), cultural and educational (vision of culture as a conceptual background of the education model), personal and developing, etc. Also, there is a distinction between socio-geographical (creation of a single op within social regions, geographical territories and states, taking into account their specifics, provided that there is a single information environment), system-integral (op as an element of social formation, as the interaction of different levels of the education system and the individual), localposter (educational space of an educational institution or its component) approaches. As a consequence, this multiplicity of manifestations and levels of op gives rise to the emergence of the latest educational paradigms and approaches (for example, a group of humanistic theories (motivational J. R. R. Tolkien). Keller, D. Goleman's emotional intelligence, E. Desi's theory of self-determination, and R. rain, etc.); theories of educational design (for example, the ADDIE model of educational design by J. R. R. Tolkien). Keller); collectivism; Democratic learning; joint learning; curicular didactics, etc.).

The formation of EA (Educational Area) occurs under the direct influence of the efforts of all its subjects: various institutions, organizations, structures and institutions of education (public, private, public), the internet, media, organized and unorganized public all those who are able to initiate indirect management and/or correlation of the educational development of an individual. The educational space as a modern socio-cultural phenomenon acts as a field of permanent interaction of various educational environments and manifestations (forms) of the educational community. This makes it necessary to select, Build and transfer the content of education in an open Information Society (Laptev V. V., Pysareva S. A., Triapytsina A. P., 2019.). On this occasion, even in the Dr. President of the Institute of information society I Masuda noted with insight: "The Information Age, which brought with IT Computer Technology and communication tools, will not only have a great socio-economic impact on modern industrial society; they will lead to social changes of such a scale that will cause the transformation of the modern system into a completely new type of human society, that is, into an information society" (Masuda Y., 1981).

Global digitalization of modern society has penetrated all its spheres without exception, affecting both social and personal aspects of human life; society is becoming more and more informational (according to the wellknown Moore's law, the amount of information doubles every ten years). Reforms of digitalization of education in the near future, which objectively requires technical and technological modernization, meets new requirements, content and trends: equipping educational institutions with modern computer equipment with appropriate peripherals and software, mass coverage of broadband high-speed internet, as well as the active introduction of mobile internet standards $4 G$ and $5 G$, wide access to various educational resources and databases, electronic scientific libraries, etc; the use of modern digital means of communication as a technological component of didactic tools, as well as the mass introduction of electronic textbooks, manuals, etc. (Popova O. Y. , 2018).

The openness of the educational space objectively creates a trend of digitalization and massization of education, primarily higher education, as it provides wide access to the best educational programs and cooperation with the best teachers of leading universities in the world. There are already many universities in the world with only distance learning in the e-learning format (so-called "Open" Universities), but the demand for Educational Services is also increasing (for example, the British Open University, which has more than 100 thousand students). Indira Gandhi Open University in India with more than a million students) (Ynformatsyonnie y kommunykatsyonnie tekhnolohyy v obrazovanyy, 2013).

The openness of modern education and the educational space constantly brings to life New, sometimes fundamentally different from traditional (for example, flipped learning (from English - "Advanced Learning") a popular format of mixed education in the last decade in the United States, Australia and New Zealand, in which the emphasis of learning is shifted to independent and extracurricular work) forms of building the educational process. It is advisable to perceive the latter as a reaction of subjects of the educational space to the latest requests for education systems and their content in the context of globalization and circization.

\section{Management of military education of future pilots}

Management of military education of future pilots is a set of knowledge about management, its regularities and principles, and forms and methods of functioning of the management system of professional military education of pilots. It defines, among other things, ways to achieve the goals of military education of tactical aviation pilots (TA). We conducted a study and generalization of the experience of managing the education of pilots and proposed methods for studying the problems of developing the management of military education, criteria and methods for evaluating the effectiveness of management and the introduction of innovative technologies.

A systematic approach to the quality of training of future pilots should be united on the principles of: priority of the training goal in the SVVO; unity of the system of professional training of pilots and as a whole and as a set of its elements; interrelation and interdependence of the 
components of the system; dynamic development of the system, adaptation to the requirements and needs of the individual; optimal management at different levels of the system; taking into account potential opportunities and contradictions, external and internal influences and challenges, comprehensive support. This leads to the introduction of innovative technologies in the educational sphere of Zvi. According to the doctor of Pedagogical Sciences, Professor I. I. Osadchenko, in pedagogical activity, the teacher should comprehend the significance of each action to achieve the goal, take into account the features of the learning process and the educational environment, the features of Personality Development, the specifics of the subject, and so on. A teacher who implements innovative technologies should adapt them to the specific conditions of the educational process (Osadchenko I. I., 2020).

Fully sharing this point of view, we note that the pedagogical context of technology application differs significantly from the production individual (subject) content - interactive interaction, emotional context and personality-oriented content. That is why the use of technologies in education requires careful balanced planning and methodological development.

So, the key characteristics and main trends of the modern educational space in the XXI century are dynamism, openness, digitalization, innovation, which gives grounds to consider it not only as a social phenomenon, but also as a functional-spatial construct in which the professional formation and self-realization of the individual takes place. Thus, the modern dynamic open educational space should be considered as a complex multi-level metasystem of the educational sphere of the modern world, within which the latest pedagogical ideas and approaches are generated and tested; the formation of new learning models; identification of key modern professional and educational competencies and which is characterized by maximum openness of didactic content, forms and tools, as well as their exchange on a global scale. New modern pedagogical constructs, subsystems and problems are components of space, gradually become its objects and acquire an institutional status.

\section{Effective system of Education Management and formation of professional competencies of future pilots}

An effective education management system for future pilots should contain: a clear training goal; processes for planning and designing the educational process; introduction of innovative information and communication and digital technologies; personnel, material and technical, financial, didactic, informational, psychological support. Management of ground training for combat flights of future pilots and should provide for control; monitoring; adjustments that are aimed at achieving the final result - high - quality training of military specialists-tactical aviation pilots.

Training activities in the SVVO during ground training are a process as a result of which the future pilot acquires new knowledge, skills, skills, improves and develops his abilities. Ground training of future pilots is a joint training activity of a research and teaching worker and a cadet, the formation of professional competencies and the acquisition of life experience. Educational activity management involves cadets performing complex intellectual actions and receiving information about the state of educational activity and its effectiveness by means of feedback.

Both the research and teaching staff and future pilots as individuals are subjects of activity and communication, which contributes to the formation of professional competence of future military pilots as a unity of four components - cognitive, praxeological, motivational, and personal.

The study of the state of development of this problem in modern Russian pedagogical science allows us to identify a number of problems that significantly hinder the formation of its modern scientific and theoretical apparatus and the strengthening of practical orientation: the lack of normative consolidation of the concept of "ground training in combat flights" in relation to future tactical aviation pilots in the military. According to Presidential Decree No. 555/2015 of 24.09.2015 "on the new version of the military doctrine of Ukraine" (Verkhovna Rada Ukraine. Zakonodavstvo Ukraine, 2015) and the organization of educational activities in the zvo of the Armed Forces of Ukraine and military training units of the zvo of Ukraine, flight training of Cadets is the main form of mastering their practical skills of piloting, navigation and combat use of aircraft, which does not provide full training for combat flights (there is practically no such type of flight training as flight-tactical training).

Flight training is carried out on the basis of theoretical training and is conducted according to flight training courses and programs that determine the content of flight training, which, in turn, contains the following stages: ground, preliminary and pre-flight training; training flights; debriefing. Therefore, ground training is a stage of flight training, during which, on the basis of theoretical training, cadets receive specific knowledge and practical skills that are necessary to perform flight exercises in piloting, navigation and combat use of aircraft.

Analysis of normative legal documents of the field of Education-Educational and professional programs (OPP, component of the standard of education) (on the example of the current OPP "flight operation and combat use of aircraft" of the first level of higher education in the specialty 253 military management (by Types of Armed Forces) of the Kharkiv National University of Air Forces named after Ivan Kozhedub) - also revealed the lack of specific formulations and definitions of ground training in combat flights of future military pilots.

There is no corresponding definition in the current scientific and methodological documents-the course of ground and flight training of cadets on a combat aircraft (KNLP BL - 2018) and the manual for flight operation of the aircraft (they use the terms "ground training", "flight training", "piloting training" and narrow profile derivatives of them). So, at the level of guiding educational documents, ground training of future tactical aviation pilots in the ZVVO as a whole and ground training in combat flights are not actually normalized or even defined, which complicates the process of their scientific institutionalization. The introduction of the concepts "ground training of future tactical aviation pilots in ZVVO" and "ground training in combat flights (ground combat training)" to the official conceptual and categorical apparatus of modern domestic military pedagogy, as well as to the list of official terms-concepts (with mandatory regulatory interpretation) in regulatory 
and scientific and methodological documents of the field of military education is updated.

It is proved that ground training in combat flights as a component of professional training of future military pilots was formed from the SER. XX century. in the context of the methodology of flight training, its content did not provide for functioning as an autonomous pedagogical subsystem and a full-fledged pedagogical construct. As a result the formation of a stable approach to this subsystem as something secondary, ignoring its propeudic essence and the lack of the necessary pedagogical theory.

\section{Modern requirements for a Ukrainian military pilot}

Modern requirements for a Ukrainian military pilot in the conditions of local military confrontation in the east of Ukraine (ATO-OOS) with the threat of its development into a full-scale interstate military conflict, the occupation of part of the territory of our state and attempts to escalate the internal political situation with incitement to separatist sentiments and support for terrorists (hybrid war) objectively dictate the need for a radical rethinking of the content of ground training in general and ground training in combat flights in particular. This rethinking will take place against the background and in the context of strategic reform of the entire national security and defense sector of our state with a central focus on strengthening the defense capability of Ukraine and strengthening the military power of the Armed Forces of Ukraine. Achieving these tasks is objectively possible under two key conditions: internal deep modernization and renewal of the Ukrainian army according to the best World models, and external - joining the most powerful modern military-political bloc of NATO.

The implementation of these conditions is impossible to imagine without modern highly professional military aviation. Thus, the concept of "American air force: a call to the future" (2014, USA) clearly states that "in modern conditions, aerospace power has become the dominant element of combat power" (America's Air Force: a Call to the Future, 2014). The 2018 NATO Air Force Strategy states that" aviation has always played a leading role in NATO's collective defense, as well as in the crisis management process" (NATO unveils new joint air power strategy, 2018). At the same time, modern requirements for military pilots are constantly expanding and increasing due to the technical improvement of aircraft and equipment, as well as with the expansion of the range of combat tasks. The latter, in turn, naturally requires the creation of a separate pedagogical system for training future military pilots in the militaryindustrial complex of Ukraine, an important part of which should be the pedagogical subsystem of ground training in combat flights.

The second condition provides for close cooperation with the North Atlantic alliance in various areas of Defense and security, including the correlation of the above-mentioned training in accordance with the standards, recommendations and best practices of NATO member countries. The strategic defense bulletin of Ukraine makes it a priority to deepen the strategic military-political, military-technical, organizational and methodological partnership with NATO. In particular, the latest national security strategy of Ukraine refers to the introduction of an integrated system of education, combat and special training of personnel for the security and defense sector bodies; the reform of the armed forces of Ukraine provides, in particular, the modernization of aviation and the air defense system of the Air Forces of the armed forces of Ukraine, ensuring their ability to respond adequately to military threats, as well as ensuring maximum compatibility of the Armed Forces of Ukraine with the Armed Forces of NATO member countries by introducing NATO standards.

The latest version of the military doctrine of Ukraine also indicates that the key tasks of creating conditions for the restoration of state sovereignty and territorial integrity of Ukraine is the development of the armed forces of Ukraine according to Western standards and achieving compatibility with the Armed Forces of NATO member states and provides for the reform of the system of military education and training. At the same time, as already noted, in the domestic sector of higher military education, there are practically no guidelines that would organizationally, and especially methodically, orient the SWO to the content and features of the actual pedagogical system for training future military pilots in general. An exception with some caution can be considered the Charter of the project "development of the system of military education and training of military specialists", jointly developed by the Ministry of defense of Ukraine and specialists of the Office of the NATO mission in Ukraine and approved by the Ministry of defense of Ukraine in 2019 to 2025 inclusive.

This document provides for the achievement in the near future of new opportunities and the development of quality indicators of Zvi using the DOTMLPFI methodology of NATO member countries; the development and filling with new content of training standards of higher military education, curricula and plans based on the testing of experimental educational and professional programs and curricula-programs of the so-called "leadership courses"; achieving the level of graduate training that ensures operational compatibility when performing joint tasks with NATO partner countries and professional training of military specialists to the level of qualification of a military specialist of the III class back in ZVVO (Statut proektu "Rozvytok system viiskovoi osvity ta pidhotovky viiskovykh fakhivtsiv", 2019). However, outside of official regulations and educational rulemaking, an extremely important aspect of theoretical and methodological filling of the content of ground training of future military pilots with modern effective scientific and pedagogical tools remains.

\section{Conclusions}

Today, there is a need to build a new global educational process in the information-technology and digital world. Technology can be considered as a universal mechanism for optimizing and structuring almost any sphere of human life in the conditions of technologization of society. This thesis is indirectly confirmed by the fact that this concept became the subject of separate study in Europe and the United States at the beginning of the twentieth century at the dawn of the formation of modern man-made civilization.

The modern technological world (technologization and technization, digitalization and informatization of society since the second half of the twentieth century) directly affects the nature of relationships in the educational space: it stimulates the search for effective alternatives to the conservative and largely narrowed traditional classroombased learning system, provokes the introduction of 
new approaches and models for building the educational process into the educational sphere, contributes to the formation of a new competence-based pedagogical paradigm based on a personality-oriented approach, freedom of didactic creativity and the concept of continuing education (the principle of "lifelong learning").

At the same time, most of the skills of professional training are developed by ground-based means using high-tech simulators. A thorough review of the features of professional training of military aviation pilots in NATO member countries, made by the author in one of the previous studies (Nevzorov R.V., 2013) demonstrates the active use of ground-based training methods and the fundamental application of digital and it technologies in training (computer modeling technologies, three-dimensional design, virtual reality, etc.), the spread of computer-field war games, the use of air bases and training grounds located in natural conditions, similar to the regions of future combat use of aviation, this in a complex confirms the significant role of ground training and its systematic scientific and theoretical base in the structure of professional training of future military pilots.

Quality management of ground training activities of future tactical aviation pilots in the conditions of military training is considered as a scientifically based system of Subject-subject interaction, which is based on the principle of a competent approach. The theoretical foundations of the concept of quality management of ground training for future pilots are: modern educational paradigms (human-centered, humanistic), the concept of continuing professional military education, personality-oriented education and competence approach. As you can see, the content of ground training in combat flights is a component of a high-quality system of professional training of future military pilots. Its clarification and updating in today's difficult realities of our state seems to us one of the important tasks of Russian military pedagogy. At the same time, one of the most significant components of this content, which fills it in the methodological sense, is the modern arsenal of pedagogical technologies.

\section{References}

[1] America's Air Force: A Call to the Future (2014). Secretary of the Air Force.

[2] Hershunskyi, B. S. (1997). Fylosofyia obrazovanyia dlia XXI veka: v poyskakh praktyko-oryentyrovannikh obrazovatelnykh kontseptsyi [Philosophy of Education for the 21st Century: in Search of Practice-Oriented Educational Concepts]. Moscow: YnterDyalekt, 287.

[3] Kasiarum, N. (2013). Osvitnii prostir: stanovlennia poniattia [Educational space: the formation of the concept]. Vytoky pedahohichnoi maisternosti - The origins of pedagogical skills, 12, 107-113.

[4] Laptev, V. V., Pysareva, S. A., \& Triapytsina, A. P. (2019). Yntehratsyia v sovremennom obrazovanyy: problema vzaymosviazy dydaktyky y metodyky obuchenyia [Integration in modern education: the problem of the relationship between didactics and teaching methods]. Yzvestyia RHPU ym. A. Y. Hertsena - Tidings RGPU im. A. I. Herzen, 192, 7-18.

[5] Masuda, Y. (1981). Ynformatsyonnoe obshchestvo [Information Society]. Washington.

[6] NATO unveils new joint air power strategy (2018) [NATO unveils new joint air power strategy]. E-source: https://www.nato.int/cps/en/natohq/news_156372.htm

[7] Nevzorov, R. V. (2013). Svitovyi dosvid pidhotovky viiskovykh lotchykiv do vykonannia boiovykh zavdan [World experience in training military pilots to perform combat missions]. Naukovi zapysky Natsionalnoho universytetu "Ostrozka akademiia». Seriia Psykholohiia i pedahohika - Scientific notes of the National University "Ostroh Academy". Psychology and pedagogy series, 25, 101-106.

[8] Nevzorov, R. V. (2019). Formuvannia fakhovoi kompetentnosti maibutnikh viiskovykh pilotiv iz zastosuvanniam zasobiv povitriano-taktychnoi pidhotovky: dys. ... kand. ped. nauk: 13.00 .04 [Formation of professional competence of future military pilots with the use of air-tactical training]. Kropyvnytskyi, $193 \mathrm{p}$.

[9] Osadchenko, I. I. (2020). Psycho-pedagogical conditions of educational environment establishment in academic institutions: problems of current Ukrainian educational reforms. Monografia. Czas na wychowanie. Radom: Wyd. Instytutu Naukowo-Wydawniczego „Spatium”, 172-182. E-source: https://dspace.udpu.edu.ua/jspui/handle/ $123456789 / 12857$

[10] Popova, O. Y. (2018). Transformatsyia vissheho obrazovanyia v uslovyiakh tsyfrovoi ekonomyky [Transformation of higher education in the digital economy]. Voprosi upravlenyia - Management issues, 54, 158-160.

[11] Statut proektu «Rozvytok systemy viiskovoi osvity ta pidhotovky viiskovykh fakhivtsiv», zatverdzhenyi Pershym zastupnykom Ministra oborony Ukrainy (18.01.2019). E-source: http://www.mil.gov.ua/ministry/normativnopravova-baza/nakazi-ministra-oboroni-ukraini/nakazi-ministerstva-oboroni-ukraini-za-2019-rik.html

[12] Verkhovna Rada Ukrainy. Zakonodavstvo Ukrainy (2015). E-source: https://zakon.rada.gov.ua/laws/show/555/ 2015\#Text]

[13] Informatsyonnie i kommunykatsyonnie tekhnolohyy v obrazovanyy: monohrafyia (2013) [Information and communication technologies in education: monograph]. Moscow: YYTO YuNESKO. 